Article

\title{
Fusaripyridines A and B; Highly Oxygenated Antimicrobial Alkaloid Dimers Featuring an Unprecedented 1,4-Bis(2-hydroxy-1,2-dihydropyridin-2-yl)butane-2,3-dione Core from the Marine Fungus Fusarium sp. LY019
}

\author{
Lamiaa A. Shaala ${ }^{1,2,3, *(\mathbb{D})}$, Torki Alzughaibi ${ }^{2,4} \mathbb{( D}$, Grégory Genta-Jouve ${ }^{5,6}$ and Diaa T. A. Youssef $7, * \mathbb{D}$ \\ 1 Natural Products Unit, King Fahd Medical Research Center, King Abdulaziz University, \\ Jeddah 21589, Saudi Arabia \\ 2 Department of Medical Laboratory Sciences, Faculty of Applied Medical Sciences, King Abdulaziz University, \\ Jeddah 21589, Saudi Arabia; taalzughaibi@kau.edu.sa \\ 3 Suez Canal University Hospital, Suez Canal University, Ismailia 41522, Egypt \\ 4 King Fahd Medical Research Center, King Abdulaziz University, Jeddah 21589, Saudi Arabia \\ 5 UMR 8038 CiTCoM, Faculté de Pharmacie de Paris, Université Paris Descartes, Avenue de l'observatoire, \\ 75006 Paris, France; gregory.genta-jouve@parisdescartes.fr \\ 6 Molecules of Communication and Adaptation of Microorganisms (UMR 7245), National Museum of \\ Natural History, CNRS, 75231 Paris, France \\ 7 Department of Natural Products, Faculty of Pharmacy, King Abdulaziz University, \\ Jeddah 21589, Saudi Arabia \\ * Correspondence: 1shalla@kau.edu.sa (L.A.S.); dyoussef@kau.edu.sa (D.T.A.Y.); \\ Tel.: +966-548-535-344 (D.T.A.Y.)
}

Citation: Shaala, L.A.; Alzughaibi, T.; Genta-Jouve, G.; Youssef, D.T.A.

Fusaripyridines A and B; Highly Oxygenated Antimicrobial Alkaloid Dimers Featuring an Unprecedented 1,4-Bis(2-hydroxy-1,2-dihydropyridin2-yl)butane-2,3-dione Core from the Marine Fungus Fusarium sp. LY019. Mar. Drugs 2021, 19, 505. https:// doi.org/10.3390/md19090505

Received: 3 August 2021

Accepted: 3 September 2021

Published: 6 September 2021

Publisher's Note: MDPI stays neutral with regard to jurisdictional claims in published maps and institutional affiliations.

Copyright: (c) 2021 by the authors Licensee MDPI, Basel, Switzerland. This article is an open access article distributed under the terms and conditions of the Creative Commons Attribution (CC BY) license (https:// creativecommons.org/licenses/by/ $4.0 /)$.
Abstract: The fungal strain, Fusarium sp. LY019, was obtained from the Red Sea sponge Suberea mollis. Bioassay-directed partition of the antimicrobial fraction of the extract of the culture of the fungus provided two dimeric alkaloids, fusaripyridines $\mathrm{A}$ and $\mathrm{B}$ ( $\mathbf{1}$ and $\mathbf{2})$. The compounds possess a previously unreported moiety, 1,4-bis(2-hydroxy-1,2-dihydropyridin-2-yl)butane-2,3-dione. Further, the compounds display a highly oxygenated substitution pattern on the dihydropyridine moieties, representing an additional feature of the fusaripyridines. Fusaripyridines A and B are the first examples of natural products possessing 1,4-bis(2-hydroxy-1,2-dihydropyridin-2-yl)butane-2,3-dione backbone. Careful analyses of the one- and two-dimensional NMR and HRESIMS spectra of the compounds secured their structural mapping, while their absolute stereochemistry was established by analyses of their ECD spectra. The production of such dimeric alkaloids with an unprecedented moiety in the culture of Fusarium sp. LY019 supports further understanding of the biosynthetic competences of the cultured marine-derived fungi. Fusaripyridines A and B selectively inhibited the growth of Candida albicans with MIC values down to $8.0 \mu \mathrm{M}$, while they are moderately active against $S$. aureus, E. coli and HeLa cells.

Keywords: Red Sea Verongiid sponge; Suberea mollis; marine-derived fungus; Fusarium sp. LY019; marine alkaloid dimers; fusaripyridines A and B; antimicrobial activity; C. albicans; cancer cell growth inhibition; HeLa cells

\section{Introduction}

Investigation of fungi of marine origin has been mostly ignored for several years as a result of their low occurrence and the doubt about their true existence. Recently, this situation has been changed due to the appreciation that marine-derived fungi embody a relatively diverse class and represent an enormous source of bioactive secondary metabolites. It was found that altering the culture conditions of the fungi, such as addition of sodium chloride for example, stimulates the production of new secondary metabolites not 
reported under regular culture conditions [1-3]. Several cultivation-dependent investigations showed that marine algae and sponges, for example, represent a massive source for fungi [2,4-7]. Moreover, an unpredicted high fungal variety was found in deep-sea hydrothermal ecosystems using molecular approaches [8]. Recently, a growing number of new fungal secondary metabolites with promising pharmaceutical bioactivities has been discovered, representing potential candidates for drug development. The biotechnological potential of the endophytic fungi has been demonstrated in different applications of the life science as antiviral agents, antifungal agents, antibacterial agents, anticancer drugs and in the biological control of different contaminants and plague $[9,10]$. Such biological properties are attributed to the unique and diverse fungal secondary metabolites with biotechnological applications and pharmaceutical importance [10,11].

Members of the genus Fusarium are widely spread in soils and plants worldwide and represent a central source of plant pathogens in agriculture [12,13]. They are also considered as a rich source of bioactive compounds. Representative examples of Fusarium-derived natural products include fusarins A, C, D, and F [14] and lucilactaene [15]. Lucilactaene, a metabolite of the Fusarium species, has received widespread attention in terms of both biosynthesis investigation and total chemical synthesis [16,17]. Lucilactaene is considered as inhibitor of cell cycle in p53-transfected cancer cells [15].

As a part of ongoing work to identify bioactive compounds of marine microbial origin [18-24], the antifungal fraction of the extract of the culture of Fusarium sp. LY019 was studied. Two novel alkaloid dimers, fusaripyridines A and B (1 and 2 ) with previously unreported highly oxygenated 1,4-bis(2-hydroxy-1,2-dihydropyridin-2-yl)butane-2,3-dione moiety, were isolated and their structures were characterized. Herein, we report about the isolation, structural determinations and the bioactivities of fusaripyridines A and B.

\section{Results and Discussion}

\subsection{Purification of Fusaripyridines $A$ and $B$ (1 and 2)}

The marine-derived fungus Fusarium sp. LY019 (Figure 1) was obtained from the inner tissue of the sponge Suberea mollis (Figure 1). Chromatographic purification of the antimicrobial fraction of the extract of the fermentation broth afforded two alkaloids, fusaripyridines A and B (1 and 2) (Figure 2).

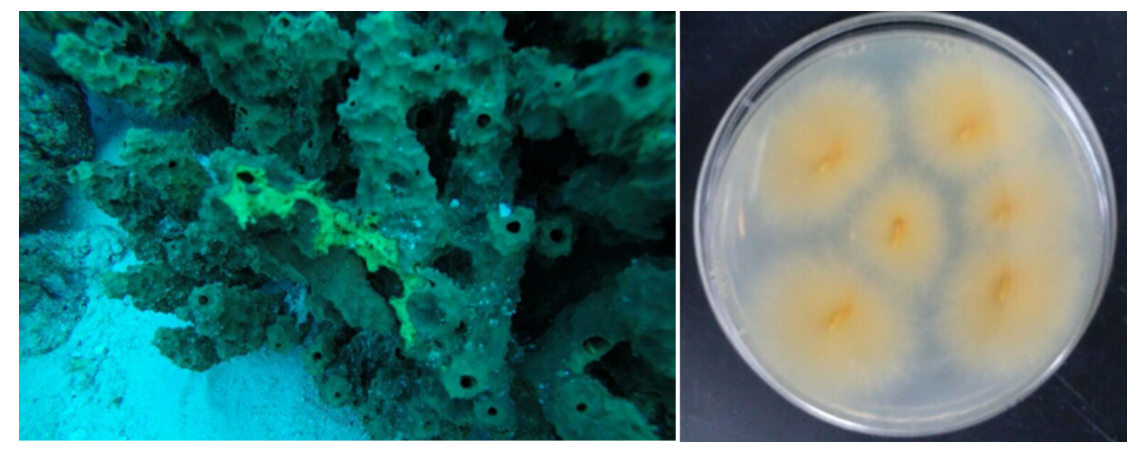

Figure 1. Photograph of the sponge Suberea mollis (left) and Fusarium sp. LY019 (right).

\subsection{Structure of Fusaripyridine $A$ (1)}

Fusaripyridine A (1) (Figure 2), an optically active compound, with molecular formula $\mathrm{C}_{18} \mathrm{H}_{24} \mathrm{~N}_{2} \mathrm{O}_{10}$ is supported by HRESIMS (Figure S1), signifying eight degrees of unsaturation. Analysis of its ${ }^{1} \mathrm{H}$ (Figure S2), ${ }^{13} \mathrm{C}$ (Figure S3) NMR spectra and COSY (Figure S4), HSQC (Figure S5), HMBC (Figure S6) and NOESY (Figure S7) experiments proofed its planar structure. Its ${ }^{13} \mathrm{C}$ NMR spectrum revealed nine signals only (Table 1 ), suggesting a symmetric dimer. The ${ }^{13} \mathrm{C}$ NMR data and the HSQC experiment allowed the assignment of the carbons into one methylene, an olefinic methine, two methoxyls $\left(\delta_{C} 59.6\right.$ and 52.4$)$, an oxygenated quaternary carbon $\left(\delta_{C} 78.2\right)$, three oxygenated aromatic carbons (132.9-166.6 ppm) and one ketone $\left(\delta_{C}\right.$ 202.1). Furthermore, its ${ }^{1} \mathrm{H}$ NMR spectrum 
exhibited resonances for an olefinic methine $\left(\delta_{\mathrm{H}} 4.98, \mathrm{~s}\right)$, one methylene $\left(\delta_{\mathrm{H}} 2.88\right.$ and 2.19, each doublet with a geminal coupling of $18.5 \mathrm{~Hz})$ and two methoxyls $\left(\delta_{\mathrm{H}} 4.01\right.$ and 3.82, each s) (Table 1). These signals are associated in the HSQC spectrum to the ${ }^{13} \mathrm{C}$ NMR signals at $\delta_{\mathrm{C}} 99.9(\mathrm{CH}), 44.8\left(\mathrm{CH}_{2}\right), 59.6\left(\mathrm{CH}_{3}\right)$ and $52.4\left(\mathrm{CH}_{3}\right)$, respectively.

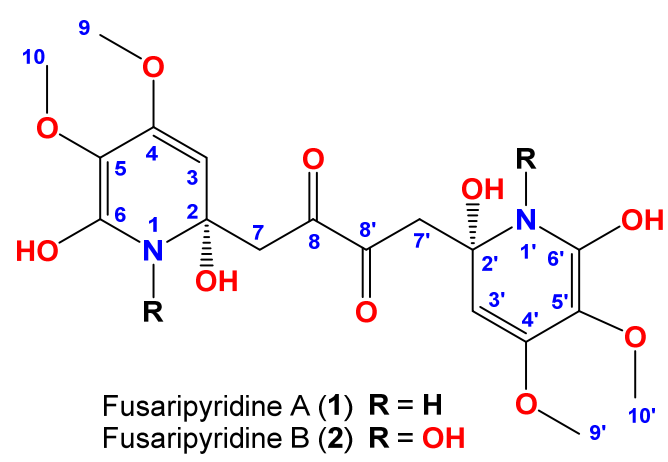

Figure 2. Chemical structures of $\mathbf{1}$ and 2.

Table 1. NMR data of fusaripyridines A (1) and B (2) (600 MHz for ${ }^{1} \mathrm{H}$ and 150 for $\left.{ }^{13} \mathrm{C}_{,} \mathrm{CD}_{3} \mathrm{OD}\right)$.

\begin{tabular}{|c|c|c|c|c|c|c|c|c|}
\hline \multirow{2}{*}{ Position } & \multicolumn{4}{|c|}{1} & \multicolumn{4}{|c|}{2} \\
\hline & $\delta_{C}$, mult. & $\delta_{\mathrm{H}}[\mathrm{m}, J(\mathrm{~Hz})]$ & НМBC & NOESY & $\delta_{C}$, mult. & $\delta_{\mathrm{H}}[\mathrm{m}, J(\mathrm{~Hz})]$ & НМВС & NOESY \\
\hline $2,2^{\prime}$ & $78.2, \mathrm{qC}$ & & $\begin{array}{l}\mathrm{H}-3 / 3^{\prime}, \\
\mathrm{H}_{2}-7 / 7^{\prime}\end{array}$ & & $77.8, \mathrm{qC}$ & & $\begin{array}{l}\mathrm{H}-3 / 3^{\prime}, \\
\mathrm{H}_{2}-7 / 7^{\prime}\end{array}$ & \\
\hline $3,3^{\prime}$ & $99.9, \mathrm{CH}$ & $4.98(\mathrm{~s})$ & $\mathrm{H}_{2}-7 / 7^{\prime}$ & & $99.5, \mathrm{CH}$ & $4.97(\mathrm{~s})$ & $\mathrm{H}_{2}-7 / 7^{\prime}$ & \\
\hline $4,4^{\prime}$ & $158.5, \mathrm{qC}$ & & $\begin{array}{c}\mathrm{H}-3, \mathrm{H}_{2}-7 \\
\mathrm{H}_{3}-9 / 9^{\prime}\end{array}$ & & $157.8, \mathrm{qC}$ & & $\begin{array}{c}\mathrm{H}-3, \mathrm{H}_{2}-7 \\
\mathrm{H}_{3}-9 / 9^{\prime}\end{array}$ & \\
\hline $5,5^{\prime}$ & $133.2, \mathrm{qC}$ & & $\begin{array}{c}\mathrm{H}-3 / 3^{\prime}, \\
\mathrm{H}_{3}-10 / 10^{\prime}\end{array}$ & & $132.9, \mathrm{qC}$ & & $\begin{array}{c}\mathrm{H}-3 / 3^{\prime}, \\
\mathrm{H}_{3}-10 / 10^{\prime}\end{array}$ & \\
\hline $6,6^{\prime}$ & $166.6, \mathrm{qC}$ & & $\begin{array}{c}\mathrm{H}_{2}-7 / 7^{\prime} \\
\mathrm{H}_{3}-10 / 10^{\prime}\end{array}$ & & $166.6, \mathrm{qC}$ & & $\begin{array}{c}\mathrm{H}_{2}-7 / 7^{\prime} \\
\mathrm{H}_{3}-10 / 10^{\prime}\end{array}$ & \\
\hline $\begin{array}{l}7 \mathrm{a}, 7 \mathrm{a}^{\prime} \\
7 \mathrm{~b}, 7 \mathrm{~b}^{\prime}\end{array}$ & $44.8, \mathrm{CH}_{2}$ & $\begin{array}{l}2.88(\mathrm{~d}, 18.5) \\
2.19(\mathrm{~d}, 18.5)\end{array}$ & $\mathrm{H}-3 / 3^{\prime}$ & $\begin{array}{l}H-7 b / b^{\prime} \\
H-7 a / a^{\prime}\end{array}$ & $44.5, \mathrm{CH}_{2}$ & $\begin{array}{l}2.88(\mathrm{~d}, 18.5) \\
2.22(\mathrm{~d}, 18.5)\end{array}$ & H-3/3' & $\begin{array}{l}H-7 b / b^{\prime} \\
H-7 a / a^{\prime}\end{array}$ \\
\hline $8,8^{\prime}$ & 202.1, qC & & $\mathrm{H}_{2}-7 / 7^{\prime}$ & & 202.0, qC & & $\mathrm{H}_{2}-7 / 7^{\prime}$ & \\
\hline $9,9^{\prime}$ & $59.6, \mathrm{CH}_{3}$ & 4.01 (s) & & $\mathrm{H}_{3}-10 / 10^{\prime}$ & $59.5, \mathrm{CH}_{3}$ & $3.99(\mathrm{~s})$ & & $\mathrm{H}_{3}-10 / 10^{\prime}$ \\
\hline $10,10^{\prime}$ & $52.4, \mathrm{CH}_{3}$ & $3.82(\mathrm{~s})$ & & $\mathrm{H}_{3}-9 / 9^{\prime}$ & $52.4, \mathrm{CH}_{3}$ & $3.81(\mathrm{~s})$ & & $\mathrm{H}_{3}-9 / 9^{\prime}$ \\
\hline
\end{tabular}

The COSY, HSQC along with the HMBC experiments allowed the assignment of three fragments within 1 including two identical fragments, namely 2,4,5,6-tetrasubstituted-1,2dihydropyridine moieties (subunits $A$ and $A^{\prime}$ ) connected symmetrically via C-2, and C-2' with a 1,4-disubstituted butane-2,3-dione moiety (subunit B) (Figure 3). The methylene signals at $\delta_{\mathrm{H} / \mathrm{C}} 2.88(\mathrm{~d}, J=18.5 \mathrm{~Hz})$ and $2.19(\mathrm{~d}, J=18.5 \mathrm{~Hz}) / 44.8\left(\mathrm{CH}_{2}, \mathrm{H}_{2}-7 / 7^{\prime}\right.$ and C-7,7') together with the ketone functionality at $\delta_{\mathrm{C}} 202.1\left(\mathrm{C}=\mathrm{O}, \mathrm{C}-8 / 8^{\prime}\right)$ constitute subunit $\mathrm{B}$. The HMBC cross-peak from $\mathrm{H}_{2}-7 / \mathrm{H}_{2}-7^{\prime}$ to the ketone moieties $\left(\delta_{\mathrm{C}} 202.1, \mathrm{C}-8 / 8^{\prime}\right)$ supported this assignment (Table 1 and Figures 3 and 4 ). The subunit $\mathrm{A}$ and $\mathrm{A}^{\prime}$ are assigned as 2,6dihydroxy-4,5-dimethoxy-1,2-dihydropyridinyl moiety as supported by the signals at $\delta_{\mathrm{H} / \mathrm{C}}$ 4.98/99.9 (CH, C-3/3'), 158.5 (qC, C-4/4'), 132.2 (qC, C-5/5'), 166.6 (qC, C-6/6'), 4.01/59.6 $\left(2 \times \mathrm{OCH}_{3}, \mathrm{H}_{3}-9 / 9^{\prime}\right.$ and $\left.\mathrm{C}-9 / 9^{\prime}\right)$ and 3.82/52.4 (2 $\times \mathrm{OCH}_{3}, \mathrm{H}_{3}-10 / 10^{\prime}$ and $\left.\mathrm{C}-10 / 10^{\prime}\right)$.

The HMBC correlations from $\mathrm{H}_{2}-7 / 7^{\prime}$ to $\mathrm{C}-2 / 2^{\prime}$ and $\mathrm{C}-3 / 3^{\prime}$ and from $\mathrm{H}-3 / 3^{\prime}$ to $\mathrm{C}-7 / 7^{\prime}$ connect subunits $\mathrm{A}$ and $\mathrm{A}^{\prime}$ with subunit $\mathrm{B}$ and confirm the placement of the olefinic carbons (C-3/3') next to the quaternary carbons C-2/2' (Figure 3).

Finally, the ${ }^{2} J_{\mathrm{CH}}$ and ${ }^{3} J_{\mathrm{CH}} \mathrm{HMBC}$ cross-peaks from $\mathrm{H}-3 / 3^{\prime}\left(\delta_{\mathrm{H}} 4.98\right)$ to $\mathrm{C}-2 / 2^{\prime}\left(\delta_{\mathrm{C}} 78.2\right)$ and $C-7 / 7^{\prime}\left(\delta_{C} 44.8\right)$ together with $\mathrm{HMBC}$ from $\mathrm{H}_{3}-9 / 9^{\prime}$ to $\mathrm{C}-4 / 4^{\prime}$ and from $\mathrm{H}_{3}-10 / 10^{\prime}$ to $\mathrm{C}-5 / 5^{\prime}$ as well as ${ }^{4} J_{\mathrm{CH}}$ from $\mathrm{H}_{3}-10 / 10^{\prime}$ to $\mathrm{C}-6 / 6^{\prime}\left(\delta_{\mathrm{C}} 166.6\right)$ supported this assignment. The HMBC cross-peaks from H-3/3' to the signals at $158.5\left(\mathrm{C}-4 / 4^{\prime}\right)$ and $133.2\left(\mathrm{C}-5 / 5^{\prime}\right)$ signify the ortho-placement of the $\mathrm{OCH}_{3}$ groups at $\mathrm{C}-4 / 4^{\prime}$ and $\mathrm{C}-5 / 5^{\prime}$ (Figures 3 and 4). 
A

B

$A^{\prime}$

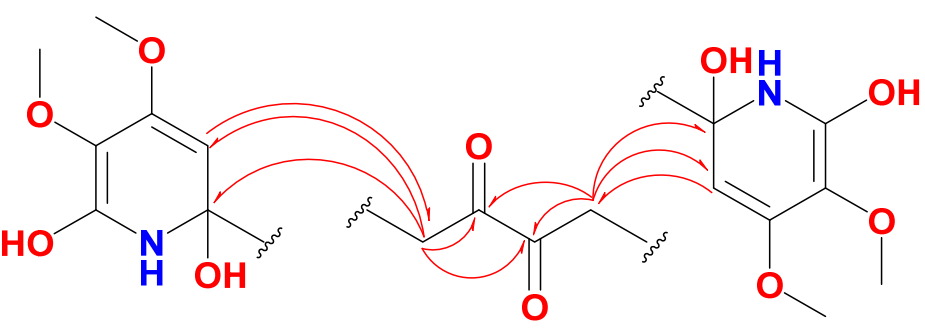

Figure 3. Structural subunits and $\mathrm{HMBC}$ connecting subunits of $\mathbf{1}$.

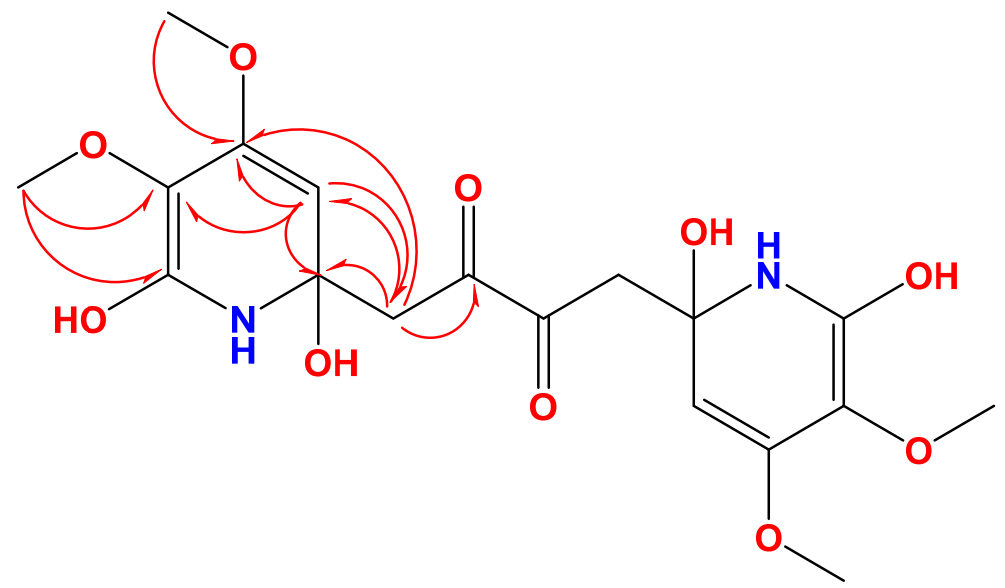

Figure 4. HMBC correlations of $\mathbf{1}$.

Finally, the ortho-substitutions of the methoxyl groups at C-4/4' and C-5/5' were confirmed from a NOESY experiment. The strong NOESY correlations observed between the methoxyl groups $\left(\mathrm{H}_{3}-9 / 9^{\prime}\right.$ and $\left.\mathrm{H}_{3}-10 / 10^{\prime}\right)$ support their ortho-position at $\mathrm{C}-4 / 4^{\prime}$ and C-5/5', respectively (Figure 5). Furthermore, the MM2-energy-minimized drawing of 1 (Figure 5) displayed strong correlations between $\mathrm{H}_{3}-9 / 9^{\prime}$ and $\mathrm{H}_{3}-10 / 10^{\prime}$ (Figure 5) confirming the ortho-substitutions of the methoxyl groups at $C-4 / 4^{\prime}$ and $C-5 / 5^{\prime}$. Thus, the 4, $4^{\prime}, 5,5^{\prime}$-tetramethoxy substitutions in $\mathbf{1}$ were confirmed.

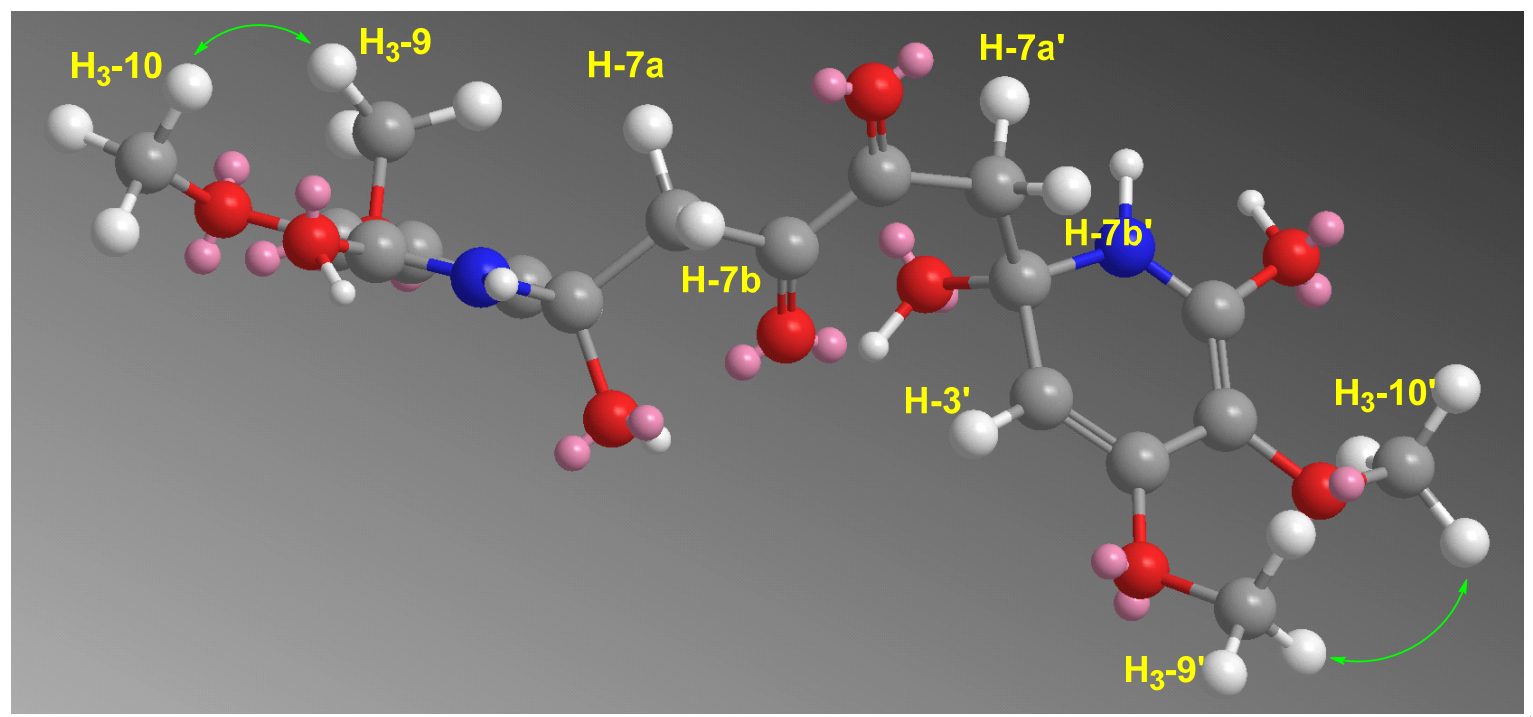

Figure 5. MM2-Energy minimized drawing of 1 displaying strong NOESY correlations between $\mathrm{H}_{3}-9 / 9^{\prime}$ and $\mathrm{H}_{3}-10 / 10^{\prime}$. 
The absolute configurations of the stereogenic carbons C-2 and C-2' in $\mathbf{1}$ are established as $2 S$ and 2 ' $S$ as supported by comparison of the predicted and experimental ECD spectra (Figure 6). The theoretical ECD spectra (Figure 6) of compound 1 were calculated for a pair of configurations, $2 S / 2^{\prime} S$ and $2 R / 2^{\prime} R$, as other combinations would result in a meso form. The computed configurations of $2 S / 2^{\prime} S$ were well in agreement with the experimental spectrum; both positive Cotton Effect (CE) are observed in the predicted spectrum at ca. 240 and $310 \mathrm{~nm}$. Thus, fusaripyridine A was assigned as 1,4-bis((S)-2,6-dihydroxy-4,5dimethoxy-1,2-dihydropyridin-2-yl)butane-2,3-dione.

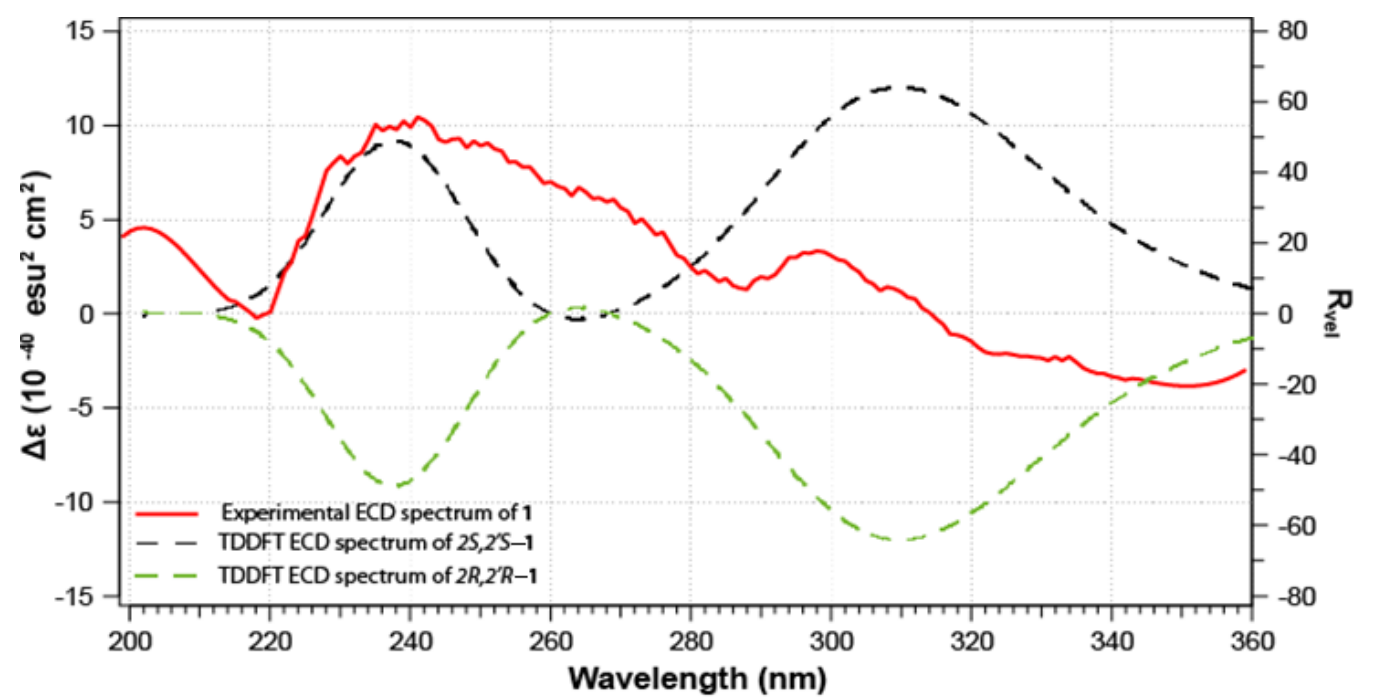

Figure 6. ECD spectra of fusaripyridine A (1).

\subsection{Structure of Fusaripyridine B (2)}

Fusaripyridine B (2) (Figure 2), an optically active compound, possesses a molecular formula $\mathrm{C}_{18} \mathrm{H}_{24} \mathrm{~N}_{2} \mathrm{O}_{12}$ as supported by HRESIMS (Figure S8), being 32 mass unit large than 1, suggesting additional two oxygen atoms in the molecule. Its ${ }^{13} \mathrm{C}$ and ${ }^{1} \mathrm{H}$ NMR spectra (Table 1) showed very close resonances to those of $\mathbf{1}$, suggesting similar structures. Further, analyses of its ${ }^{1} \mathrm{H}$ (Figure S9), ${ }^{13} \mathrm{C}$ (Figure S10), NMR spectra, COSY (Figure S11), HSQC (Figure S12), HMBC (Figure S13) and NOESY (Figure S14) experiments confirmed its planar structure. Therefore, the oxygen atoms accounted for two additional hydroxy groups located at $N-1$ and $N-1^{\prime}$, the sole positions allowed for substitution in 2 .

Fusaripyridine $B(2)$ shares the sign and magnitude of the optical rotation $\left([\alpha]_{D}=+23^{\circ}\right)$ with fusaripyridine $A(1)\left([\alpha]_{D}=+27^{\circ}\right)$. Therefore, we anticipate that 2 shares the biosynthetic pathway as 1 and possesses the same absolute configuration of $2 S / 2^{\prime} S$. Thus, fusaripyridine B was assigned as 1,4-bis((S)-1,2,6-trihydroxy-4,5-dimethoxy-1,2dihydropyridin-2-yl)butane-2,3-dione.

Natural $N$-substituted alkaloids are common secondary metabolites that reported from different terrestrial, marine and microbial organisms [25-31]. Reported substituents on the $\mathrm{N}$ atoms include $\mathrm{OH}$, hydroperoxy, alkyl, heteroaromatic functionalities, and others [25-31]. Thus, fusaripyridine B represents an additional example of these alkaloids with $N, N^{\prime}-\mathrm{OH}$ functionalities.

\subsection{Biological Evaluation of the Compounds}

The fusaripyridines A (1) and B (2) are evaluated, in a disc diffusion assay, for their antimicrobial effects against C. albicans, E. coli and S. aureus at a concentration of $50 \mu \mathrm{g} / \mathrm{disc}$. The compounds displayed potent antifungal effects against $C$. albicans with inhibition zones of 26 and $24 \mathrm{~mm}$, and with MIC values of 8.0 and $8.0 \mu \mathrm{M}$, respectively. Further, the compounds displayed weak growth inhibition towards $S$. aureus and E. coli with MIC of $\geq 32.0 \mu \mathrm{M}$ (Table 2). Moreover, fusaripyridines A (1) and B (2) showed weak effects towards 
HeLa cells with $\mathrm{IC}_{50}$ of $\geq 25 \mu \mathrm{M}$. The above data suggest the selectivity of the $C$. albicans towards fusaripyridines $\mathrm{A}$ and $\mathrm{B}$.

Table 2. Antimicrobial activities of fusaripyridines A and B.

\begin{tabular}{|c|c|c|c|c|c|c|}
\hline \multirow[b]{2}{*}{ Compound } & \multicolumn{2}{|c|}{ C. albicans } & \multicolumn{2}{|c|}{ E. coli } & \multicolumn{2}{|c|}{ S. aureus } \\
\hline & $\begin{array}{l}\text { Inhibition } \\
\text { Zone(mm) }\end{array}$ & $\operatorname{MIC}(\mu \mathrm{M})$ & $\begin{array}{l}\text { Inhibition } \\
\text { Zone(mm) }\end{array}$ & $\operatorname{MIC}(\mu \mathrm{M})$ & $\begin{array}{l}\text { Inhibition } \\
\text { Zone(mm) }\end{array}$ & $\operatorname{MIC}(\mu \mathrm{M})$ \\
\hline Fusaripyridine A (1) & 26 & 8.0 & 9 & $\geq 32$ & 9 & $\geq 32$ \\
\hline Fusaripyridine B (2) & 24 & 8.0 & 7 & $\geq 32$ & 8 & $\geq 32$ \\
\hline Ketoconazole $^{\mathrm{a}}$ & 30 & 0.26 & - & - & - & - \\
\hline Ciprofloxacin ${ }^{b}$ & - & - & 30 & 0.08 & 22 & 0.16 \\
\hline
\end{tabular}

${ }^{a}$ Positive antifungal drug; ${ }^{b}$ positive antibacterial drug.

\section{Materials and Methods}

\subsection{General Experimental Procedures}

Optical rotations values were measured on a digital DIP-370 polarimeter (JASCO, Oklahoma City, OK, USA), while the UV spectra are obtained on a Hitachi 300 spectrometer (Hitachi High-Technologies Corporation, Kyoto, Japan). The ECD spectra were obtained on a JASCO J-810 spectropolarimeter (JASCO, Oklahoma City, OK, USA) with a $0.5 \mathrm{~cm}$ cell in $\mathrm{MeOH}$. The NMR spectra were acquired on Bruker Avance DRX $600 \mathrm{MHz}$ spectrometer (Bruker, Rheinstetten, Germany). Positive ion HRESIMS spectra were obtained on a Thermo LTQ Orbitrap XL mass spectrometer (Thermo Finnigan, Bremen, Germany). Normal $\mathrm{SiO}_{2}$ (Merck, Darmstadt, Germany) and Sephadex LH 20 (Pharmacia, Uppsala, Sweden) were used for chromatography.

\subsection{Host Organism, Suberea mollis}

The Red Sea sponge Suberea mollis (Figure 1) was harvested by hand using scuba from Yanbu at the Saudi Red Sea at a depth of $-30 \mathrm{~m}$. Description of the sponge was reported earlier in details [32].

\subsection{Preparation of the Fungal Isolate LY019}

The fungal isolate Fusarium sp. LY019 was isolated from the Red Sea sponge Suberea mollis by culturing on Czapek-Dox yeast agar medium $\left(\mathrm{K}_{2} \mathrm{HPO}_{4} 0.1 \mathrm{~g}, \mathrm{MgSO}_{4} \cdot 7 \mathrm{H}_{2} \mathrm{O} 0.5 \mathrm{~g}\right.$, $\mathrm{NaNO}_{3} 3.0 \mathrm{~g}$, $\mathrm{KCl} 0.5 \mathrm{~g}, \mathrm{FeSO}_{4} 0.01 \mathrm{~g}$, sucrose 30.0 g, agar $20.0 \mathrm{~g}$, pH 6.7), using several purification steps until a pure isolate was obtained. After that, the isolate was inoculated into $50 \mathrm{~mL}$ of Czapek-Dox broth in $200 \mathrm{~mL}$ flasks at $\mathrm{pH} 7$ and was incubated at $160 \mathrm{rpm}$, $25^{\circ} \mathrm{C}$ for 7 days.

\subsection{Preparation of Genomic DNA of Isolate LY019}

Subculture of the isolate in corresponding broth for 4 days at $25^{\circ} \mathrm{C}$ was carried out. Afterwards the mycelia were separated using a vacuum filtration unit. The mycelial mat was dried and powdered. The fungal DNA was obtained using QIAamp DNA Mini Kit (Qiagen, Hilden, Duesseldorf, Germany) as stated by the manufacturer.

\subsection{Amplification of ITS-rDNA Fragments of Isolate LY019}

Using ITS1 and ITS4 primers, the genomic DNA was served as the template for amplification of the fungal ITS-rDNA fragments [33]. The PCR reaction mixture for amplification and the reaction conditions are similar with previous work [22]. The agarose Gel DNA purification kit (Qiagen, Hilden, Duesseldorf, Germany) was used for purification of the PCR products. 


\subsection{Sequence of ITS-rDNA Regions of Isolate LY019}

The sequence of the ITS-rDNA regions was compared with correlated sequences in NCBI [34]. Editing and alignment of the ITS-rDNA sequence with the best n-BLAST hits in GenBank were obtained using the Clustal X (version 1.83) program (Conway Institute, University College Dublin) [35]. The adjustment was achieved using BioEdit software (Bioz, Inc., Los Altos, Ca 94022, USA) manually [36]. MEGA 5 program was used for the base composition of the sequence [37].

\subsection{Characterization of the Fungal Isolate LY019}

The resulted sequence analysis exhibited 99\% identity with Fusarium commune (NCIB accession number KU891512).

\subsection{Fermentation and Extraction of the Broth}

The fermentation was obtained in a $2.8 \mathrm{~L}$ Fernbach flasks with one liter of Czapek-Dox medium (Difco) containing 3\% $\mathrm{NaCl}(w / v)$. Each flask was inoculated with $10 \mathrm{~mL}$ of the seed followed by incubation at $27^{\circ} \mathrm{C}$ and $180 \mathrm{rpm}$ for 10 days. After that, each flask was mixed with ethyl acetate $(500 \mathrm{~mL} \times 2)$ and shaken at $1800 \mathrm{rpm}$ for $30 \mathrm{~min}$. The organic phase was separated and dried under vacuum.

\subsection{Purification of Fusaripyridines $A$ and $B$}

The dried extract $(1.8 \mathrm{~g})$ was partitioned on silica gel using hexane- $\mathrm{CHCl}_{3}-\mathrm{MeOH}$ gradients to give five fractions. The antifungal fraction (inhibition zone of $12 \mathrm{~mm}$ at $50 \mu \mathrm{g} / \mathrm{disc}$ against $C$. albicans) eluted with $\mathrm{CHCl}_{3}-\mathrm{MeOH}(98: 2)$ (Fr. 5, $113 \mathrm{mg}$ ) was fractionated again on Sephadex LH-20 eluted with $\mathrm{MeOH}$ to give four major subfractions. Subfraction 4 $(37.0 \mathrm{mg})$ was purified on a Gemini HPLC Column $(5 \mu \mathrm{m} \mathrm{C18} 110 \AA, 250 \times 4.6 \mathrm{~mm})$ using $\mathrm{CH}_{3} \mathrm{CN}-\mathrm{H}_{2} \mathrm{O}(1: 1)$ at $1.0 \mathrm{~mL} / \mathrm{min}$ to give compounds $\mathbf{1}\left(\mathrm{t}_{R}=4.3 \mathrm{~min}, 3.5 \mathrm{mg}\right)$ and 2 $\left(\mathrm{t}_{R}=5.4 \mathrm{~min}, 1.4 \mathrm{mg}\right)$.

Spectral Data of Fusaripyridines A and B

Fusaripyridine A (1): colorless solid; $[\alpha]_{\mathrm{D}}=+27^{\circ}(c 0.1, \mathrm{MeOH}) ; \mathrm{UV}(\mathrm{MeOH}): \lambda_{\max }(\log$ ع): 252 (2.76) nm; NMR data: Table 1; HRESIMS: $m / z 451.1332$ (calcd for $\mathrm{C}_{18} \mathrm{H}_{24} \mathrm{~N}_{2} \mathrm{O}_{10} \mathrm{Na}$, $\left.[\mathrm{M}+\mathrm{Na}]^{+}, 451.1323\right)$.

Fusaripyridine B (2): colorless solid; $[\alpha]_{\mathrm{D}}=+23^{\circ}\left(c\right.$ 0.1, MeOH); UV $(\mathrm{MeOH}): \lambda_{\max }(\log$ ع): 252 (2.76) nm; NMR data: Table 1; HRESIMS: $m / z 483.1230$ (calcd for $\mathrm{C}_{18} \mathrm{H}_{24} \mathrm{~N}_{2} \mathrm{O}_{12} \mathrm{Na}$, $\left.[\mathrm{M}+\mathrm{Na}]^{+}, 483.1221\right)$.

\subsection{Computational Details}

Calculations of the DFT are performed using Gaussian 16 W [38]. A conformation analysis using the GMMX plugin followed by a geometry optimization at the B3LYP/6$31 \mathrm{~g}(\mathrm{~d})$ level was conducted. Similarly, a frequency check at the same level of theory was performed. In addition, a $0.5 \mathrm{kcal} . \mathrm{mol}^{-1}$ cutoff was used to select only the most stable conformer. Rotational strengths were calculated on 20 excited states using the b3lyp/6$31 \mathrm{~g}(\mathrm{~d})$ level of theory. Finally, Gaussview 6 was used to plot the ECD spectra. The XYZ coordinates of the most stable conformer was added in the supporting data (Supporting data s2).

\subsection{Antimicrobial Activities of the Compounds}

The antimicrobial effects of $\mathbf{1}$ and $\mathbf{2}$ against $C$. albicans, E. coli and S. aureus were carried out at $50 \mu \mathrm{g} /$ disc as previously reported in a disk diffusion assay [39-42].

\subsection{Evaluation of the MIC}

Determination of the MIC of $\mathbf{1}$ and $\mathbf{2}$ against C. albicans, E. coli and S. aureus was performed in a macrodilution assay as described earlier [40,43]. 


\subsection{MTT Assay}

The antiproliferative and growth inhibition activities of $\mathbf{1}$ and $\mathbf{2}$ were carried out on HeLa cells (ATCC CCL-2) in MTT assay as reported earlier [44-47].

\section{Conclusions}

The organic extract of the fungus Fusarium sp. LY019 yielded two alkaloids, fusaripyridines A (1) and B (2), with an unprecedented 1,4-bis(2-hydroxy-1,2-dihydropyridin-2-yl)butane2,3-dione backbone. Analyses of the spectroscopic data (NMR and HRESIMS) supported the planar structures of $\mathbf{1}$ and $\mathbf{2}$, while the absolute configurations were obtained from the comparison of their ECD spectra. Fusaripyridines A and B are highly oxygenated alkaloids on the dihydropyridine moieties and represent the first candidates in this class. The compounds displayed selective and potent activities towards C. albicans with MIC values of 8.0 and $8.0 \mu \mathrm{M}$. The current results highlight the biosynthetic competences of fungi of marine origin as a foundation of drug leads with pharmaceutical potential. Fusaripyridines A and B could serve as a model for the discovery of novel antibiotics.

Supplementary Materials: The following are available online at https:/ / www.mdpi.com/article/10 $.3390 / \mathrm{md19090505/s1,} \mathrm{Figures} \mathrm{S1-S14:} \mathrm{HRESIMS,}{ }^{1} \mathrm{HNMR},{ }^{13}$ C NMR, DEPT, COSY, HSQC, HMBC, and NOESY spectra of fusaripyridines A (1) and B (2), XYZ coordinates of the most stable conformer of fusaripyridine A (1).

Author Contributions: Conceptualization, D.T.A.Y. and L.A.S.; methodology, L.A.S., D.T.A.Y. and T.A.; formal analysis, D.T.A.Y., L.A.S., G.G.-J. and T.A.; software, G.G-J.; investigation, D.T.A.Y. and L.A.S.; resources, D.T.A.Y.; data curation, L.A.S., T.A., G.G.-J. and D.T.A.Y.; writing-original draft preparation, L.A.S. and D.T.A.Y.; writing-review and editing, L.A.S. and D.T.A.Y.; supervision, L.A.S. and D.T.A.Y.; project administration, L.A.S.; funding acquisition, L.A.S. and D.T.A.Y. All authors have read and agreed to the published version of the manuscript.

Funding: This research was funded by Deputyship for Research \& Innovation, Ministry of Education in Saudi Arabia, grant number 1317.

Data Availability Statement: Data is contained within the article or supplementary material.

Acknowledgments: The authors extend their appreciation to the Deputyship for Research \& Innovation, Ministry of Education in Saudi Arabia for funding this research work through the project number (1317). We thank Rob van Soest for identification of the sponge material.

Conflicts of Interest: The authors declare no conflict of interest.

\section{References}

1. Bringmann, G.; Gulder, T.A.M.; Lang, G.; Schmitt, S.; Stöhr, R.; Wiese, J.; Nagel, K.; Imhoff, J.F. Large scale biotechnological production of the antileukemic marine natural product sorbicillactone A. Mar. Drugs 2007, 5, 23-30. [CrossRef]

2. Wiese, J.; Ohlendorf, B.; Blümel, M.; Schmaljohann, R.; Imhoff, J.F. Phylogenetic identification of fungi isolated from the marine sponge Tethya aurantium and identification of their secondary metabolites. Mar. Drugs 2011, 9, 561-585. [CrossRef]

3. Lang, G.; Wiese, J.; Schmaljohann, R.; Imhoff, J.F. New pentaenes from the sponge-derived marine fungus Penicillium rugulosum: Structure determination and biosynthetic studies. Tetrahedron 2007, 63, 11844-11849. [CrossRef]

4. Zhang, Y.; Mu, J.; Feng, Y.; Kang, Y.; Zhang, J.; Gu, P.J.; Wang, Y.; Ma, L.F.; Zhu, Y.H. Broad-spectrum antimicrobial epiphytic and endophytic fungi from marine organisms: Isolation, bioassay and taxonomy. Mar. Drugs 2009, 7, 97-112. [CrossRef]

5. Paz, Z.; Komon-Zelazowska, M.; Druzhinina, I.S.; Aveskamp, M.M.; Schnaiderman, A.; Aluma, A.; Carmeli, S.; Ilan, M.; Yarden, O. Diversity and potential antifungal properties of fungi associated with a Mediterranean sponge. Fungal Divers. 2010, 42, 17-26. [CrossRef]

6. Rateb, M.E.; Ebel, R. Secondary metabolites of fungi from marine habitats. Nat. Prod. Rep. 2011, 28, 290-344. [CrossRef]

7. Bugni, T.S.; Ireland, C.M. Marine-derived fungi: A chemically and biologically diverse group of microorganisms. Nat. Prod. Rep. 2004, 21, 143-163. [CrossRef]

8. Le Calvez, T.; Burgaud, G.; Mahe, S.; Barbier, G.; Vandenkoornhuyse, P. Fungal diversity in deep-sea hydrothermal ecosystems. Appl. Environ. Microbiol. 2009, 75, 6415-6421. [CrossRef]

9. El-Bondkly, E.A.M.; El-Bondkly, A.A.M.; El-Bondkly, A.A.M. Marine endophytic fungal metabolites: A whole new world of pharmaceutical therapy exploration. Heliyon 2021, 7, e06362. [CrossRef] 
10. Jeewon, R.; Luckhun, A.B.; Bhoyroo, V.; Sadeer, N.B.; Mahomoodally, M.F.; Rampadarath, S.; Puchooa, D.; Sarma, V.V.; Durairajan, S.S.K.; Hyde, K.D. Pharmaceutical potential of marine fungal endophytes. In Endophytes and Secondary Metabolites, Reference Series in Phytochemistry; Jha, S., Ed.; Springer International Publishing: Basel, Switzerland; Cham, Switzerland, 2019 ; pp. $283-305$.

11. Tan, R.X.; Zou, W.X. Endophytes: A rich source of functional metabolites. Nat. Prod. Rep. 2001, 18, 448-459. [CrossRef]

12. Thrane, U. Screening for fusarin C production by European isolates of Fusarium species. Mycotoxin Res. 1988, 4, 2-10. [CrossRef]

13. Nash, S.M.; Snyder, W.C. Quantitative and qualitative comparisons of Fusarium populations in cultivated fields and noncultivated parent soils. Can. J. Bot. 1965, 43, 939-945. [CrossRef]

14. Kleigrewe, K.; Aydin, F.; Hogrefe, K.; Piecuch, P.; Bergander, K.; Wuerthwein, E.-U.; Humpf, H.-U. Structure elucidation of new fusarins revealing insights in the rearrangement mechanisms of the Fusarium mycotoxin fusarin C. J. Agric. Food Chem. 2012, 60, 5497-5505. [CrossRef]

15. Kakeya, H.; Kageyama, S.; Nie, L.; Onose, R.; Okada, G.; Beppu, T.; Norbury, C.J.; Osada, H. Lucilactaene, a new cell cycle inhibitor in p53-transfected cancer cells, produced by a Fusarium sp. J. Antibiot. 2001, 54, 850-854. [CrossRef]

16. Kato, S.; Motoyama, T.; Futamura, Y.; Uramoto, M.; Nogawa, T.; Hayashi, T.; Hirota, H.; Tanaka, A.; Takahashi-Ando, N.; Kamakura, T.; et al. Biosynthetic gene cluster identification and biological activity of lucilactaene from Fusarium sp. RK97-94. Biosci. Biotechnol. Biochem. 2020, 84, 1303-1307. [CrossRef]

17. Coleman, R.S.; Walczak, M.C.; Campbell, E.L. Total synthesis of lucilactaene, a cell cycle inhibitor active in p53-inactive cells. J. Am. Chem. Soc. 2005, 127, 16038-16039. [CrossRef] [PubMed]

18. Youssef, D.T.A.; Alahdal, A.M. Cytotoxic and antimicrobial compounds from the marine-derived fungus, Penicillium species. Molecules 2018, 23, 394. [CrossRef] [PubMed]

19. Mourshid, S.A.; Badr, J.M.; Risinger, A.L.; Mooberry, S.L.; Youssef, D.T.A. Penicilloitins A and B, new antimicrobial fatty acid esters from a marine endophytic Penicillium species. Z. Naturforsch. C 2016, 71, 387-392. [CrossRef]

20. Murshid, S.S.A.; Badr, J.M.; Youssef, D.T.A. Penicillosides A and B: New cerebrosides from the marine-derived fungus Penicillium species. Rev. Bras. Farmacogn. 2016, 26, 29-33. [CrossRef]

21. Asiry, I.A.M.; Badr, J.M.; Youssef, D.T.A. Penicillivinacine, antimigratory diketopiperazine alkaloid from the marine-derived fungus Penicillium vinaceum. Phytochem. Lett. 2015, 13, 53-58. [CrossRef]

22. Shaala, L.A.; Youssef, D.T.A. Identification and bioactivity of compounds from the fungus Penicillium sp. CYE-87 isolated from a marine tunicate. Mar. Drugs 2015, 13, 1698-1709. [CrossRef]

23. Shaala, L.A.; Youssef, D.T.A.; Alzughaibi, T.; Elhady, S.S. Antimicrobial chlorinated 3-phenylpropanoic acid derivatives from the Red Sea marine actinomycete Streptomyces coelicolor LY001. Mar. Drugs 2020, 18, 450. [CrossRef]

24. Shaala, L.A.; Youssef, D.T.A.; Badr, J.M.; Harakeh, S.M.; Genta-Jouve, G. Bioactive diketopiperazines and nucleoside derivatives from a sponge-derived Streptomyces species. Mar. Drugs 2019, 17, 584. [CrossRef] [PubMed]

25. Nakamura, N.; Hirakawa, A.; Gao, J.; Kakuda, H.; Shiro, M.; Komatsu, Y.; Sheu, C.; Hattori, M. Five new maleic and succinic acid derivatives from the mycelium of Antrodia camphorata and their cytotoxic effects on LLC tumor cell line. J. Nat. Prod. 2004, 67, 46-48. [CrossRef] [PubMed]

26. Xue, C.; Li, T.; Deng, Z.; Fu, H.; Lin, W. Janthinolide A-B, two new 2,5-piperazinedione derivatives from the endophytic Penicillium janthinellum isolated from the soft coral Dendronephthya sp. Pharmazie 2006, 61, 1041-1044. [CrossRef] [PubMed]

27. Qin, L.; Yi, W.; Lian, X.; Zhang, Z. Bioactive alkaloids from the actinomycete Actinoalloteichus sp. ZZ1866. J. Nat. Prod. 2020, 83, 2686-2695. [CrossRef]

28. Youssef, D.T.A. Alkaloids of the flowers of Hippeastrum vittatum. J. Nat. Prod. 2001, 64, 839-841. [CrossRef]

29. Costa, E.V.; Pinheiro, M.L.; Xavier, C.M.; Silva, J.R.A.; Amaral, A.C.F.; Souza, A.D.L.; Barison, A.; Francinete, R.; Campos, F.R.; Ferreira, A.G.; et al. A Pyrimidine- $\beta$-carboline and other alkaloids from Annona foetida with antileishmanial activity. J. Nat. Prod. 2006, 69, 292-294. [CrossRef]

30. Chan, S.T.S.; Pearce, A.N.; Page, M.J.; Kaiser, M.; Brent, R.; Copp, B.R. Antimalarial $\beta$-carbolines from the New Zealand ascidian Pseudodistoma opacum. J. Nat. Prod. 2011, 74, 1972-1979. [CrossRef]

31. de Oliveira, A.L.L.; da Silva, D.B.; Debonsi, N.P.L.H.M.; Yokoya, N.S. Chemical constituents from red algae Bostrychia radicans (Rhodomelaceae): New amides and phenolic compounds. Quím. Nova 2012, 35, 2186-2188. [CrossRef]

32. Shaala, L.A.; Khalifa, S.I.; Mesbah, M.K.; van Soest, R.W.M.; Youssef, D.T.A. Subereaphenol A, a new cytotoxic and antimicrobial dibrominated phenol from the Red Sea sponge Suberea mollis. Nat. Prod. Commun. 2008, 3, 219-222. [CrossRef]

33. White, T.J.; Bruns, T.; Lee, S.; Taylor, J. Amplification and Direct Sequencing of Fungal Ribosomal RNA Genes for Phylogenetics. In PCR Protocols: A Guide to Methods and Application; Innis, M.A., Gelfand, D.H., Sninsky, J.J., White, T.J., Eds.; Academic Press: San Diego, CA, USA, 1990; pp. 315-322.

34. National Center for Biotechnology Information. Available online: http:/ / www.ncbi.nlm.nih.gov (accessed on 19 June 2021).

35. Thompson, J.D.; Gibson, T.J.; Plewniak, F.; Jeanmougin, F.; Higgins, D.G. The ClustalX windows interface: Flexible strategies for multiple sequence alignment aided by quality analysis tools. Nucleic Acids Res. 1997, 25, 4876-4882. [CrossRef]

36. Hall, T.A. BioEdit: A user friendly biological sequence alignment editor and analysis program for Windows 95/98/NT. Nucleic Acids Symp. Ser. 1999, 41, 95-98.

37. Tamura, K.; Peterson, D.; Peterson, N.; Stecher, G.; Nei, M.; Kumar, S. MEGA5: Molecular evolutionary genetics analysis using maximum likelihood, evolutionary distance, and maximum parsimony methods. Mol. Biol. Evol. 2011, 28, 2731-2739. [CrossRef] 
38. Frisch, M.J.; Trucks, G.W.; Schlegel, H.B.; Scuseria, G.E.; Robb, M.A.; Cheeseman, J.R.; Scalmani, G.; Barone, V.; Mennucci, B.; Petersson, G.A.; et al. G09a: Gaussian 09, Revision A.02; Gaussian Inc.: Wallingford, CT, USA, 2009.

39. Kiehlbauch, J.A.; Hannett, G.E.; Salfinger, M.; Archinal, W.; Monserrat, C.; Carlyn, C. Use of the National Committee for Clinical Laboratory Standards Guidelines for Disk Diffusion Susceptibility Testing in New York State Laboratories. J. Clin. Microbiol. 2000, 38, 3341-3348. [CrossRef]

40. Shaala, L.A.; Youssef, D.T.A. Pseudoceratonic acid and moloka'iamine derivatives from the Red Sea Verongiid sponge Pseudoceratina arabica. Mar. Drugs 2020, 18, 525. [CrossRef]

41. Acar, J.F. The disc susceptibility test. In Antibiotics in Laboratory Medicine; Lorian, V., Ed.; Williams \& Wilkins: Philadelphia, PA, USA, 1980; pp. 24-54.

42. Youssef, D.T.A.; Asfour, H.Z.; Genta-Jouve, G.; Shaala, L.A. Magnificines A and B, antimicrobial marine alkaloids featuring a tetrahydrooxazolo [3,2-a] azepine-2,5 (3H, 6H)-dione backbone from the Red Sea sponge Negombata magnifica. Mar. Drugs 2021, 19, 214. [CrossRef]

43. CLSI. CLSI Documents M07-A9. Performance Standards for Antimicrobial Disk Susceptibility Tests, 9th ed.; Clinical and Laboratory Standards Institute: Wayne, PA, USA, 2007.

44. Youssef, D.T.A.; Asfour, H.Z.; Shaala, L.A. Psammaceratin A: A cytotoxic psammaplysin dimer featuring an unprecedented (2Z,3Z)-2,3-bis(aminomethylene)succinamide backbone from the Red Sea sponge Pseudoceratina arabica. Mar. Drugs 2021, 19, 433. [CrossRef]

45. Shaala, L.A.; Youssef, D.T.A. Cytotoxic psammaplysin analogues from the Verongid Red Sea sponge Aplysinella species. Biomolecules 2019, 9, 841. [CrossRef]

46. Abou-Hussein, D.R.; Youssef, D.T.A. Mirabolides A and B.; New cytotoxic glycerides from the Red Sea sponge Theonella mirabilis. Mar. Drugs 2016, 14, 155. [CrossRef]

47. Youssef, D.T.A.; Mooberry, S.L. Hurghadolide A and swinholide I, potent actin-microfilament disrupters from the Red Sea sponge Theonella swinhoei. J. Nat. Prod. 2006, 69, 154-157. [CrossRef] [PubMed] 